\title{
BASIC PRINCIPLES ON WHICH THE DEVELOPMENT OF EDUCATIONAL ENVIRONMENTAL WORKS IS BASED
}

\section{БАЗОВІ ПРИНЦИПИ, НА ЯКИХ ГРУНТУЕТЬСЯ РОЗРОБКА НАВЧАЛЬНИХ ЕКОЛОГІЧНИХ ТВОРІВ}

\author{
Yuliia Nizhynska ${ }^{1}$ \\ Liudmyla Datsenko
}

DOI: https://doi.org/10.30525/978-9934-588-15-0-141

Abstract. Deterioration of the environmental situation in the world requires the constant environmental education of the younger generation, in particular, as well as of the whole population. Cartographic materials are an effective visual tool for the accumulation of knowledge about the patterns of development and functioning of natural complexes (ecosystems), the formation of ecological culture. One of the priorities of society is the ecological education of students which should occur primarily through the educational environment of the school. Environmental education is key for respecting nature and for achieving international agendas, including the Millennium Development Goals (MDGs); the Convention on Biological Diversity (CBD); the United Nations Convention to Combat Desertification (UNCCD); and the United Nations Decade of Education for Sustainable Development (UNDESD, 2005-2014). The process of teaching ecology at school is continually accompanied by the use of such a visual manual as a map. Herewith, the card, which is provided in the form of separate educational material (wall map, in the collection of maps - atlas) or included in the textbook, serves not only as an accessory means of learning (accompanying the teacher's explanations, illustrating some occurrences and phenomena), but also as an independent means of education and upbringing. The relevance of the problem is due to the fact that in the conditions of the modern school the use of visual aids such as maps (paper and electronic) is urgently

\footnotetext{
${ }^{1}$ Graduate Student,

Taras Shenchenko National University of Kiev, Ukraine

${ }^{2}$ Doctor of Science in Geography (Geographical Cartography),

Professor (Geodesy and Cartography)

Taras Shenchenko National University of Kiev, Ukraine
} 
needed. First of all, because of an intense increase in the information flow that is hitting a modern person (both a student and a teacher), it is difficult for a teacher to choose the necessary and useful pieces of information. A visual manual solves the problem of providing a great deal of information, when the organs of hearing and vision are simultaneously involved in the learning process, its effectiveness is greatly increased. Thus, for example, it is enough for a teacher to point to any object or phenomenon on the map, then the pupils will receive much more information about it, record in space and properly remember it. Thereby, the map eliminates the need for long, monotonous explanations, releasing this time to explore other equally important topics. At the same time, changing the form of explaining teaching material does not affect the learning process negatively; on the contrary, it facilitates learning and memorizing the material for a longer period of time. The object of the study is school cartographic materials on ecology. The subject is theoretical and practical positions for the development of the atlas structure and the system of cartographic indicators of ecological maps. The main purpose of this paper is to investigate the existing basic principles to be followed when drawing up environmental maps for the school.

\section{1. Вступ}

Сучасне суспільство висуває перед школою багато вимог, 3-поміж яких - формування умінь, знань та навичок, необхідних у дорослому житті.

На підставі компетентнісного підходу знання мають стати не багажем «про всяк випадок», а ключем до розв'язання проблем, забезпечення успішної самореалізації у соціумі, облаштування особистого життя. Сьогодні неможливо навчити дитину всього, значно важливіше сформувати в неї потребу в неперервній освіті. Тому зміст навчального матеріалу з географії визначено з огляду на корисність та потрібність його за межами школи.

В програмі з географії для 6-9 класів виокремлено компетентнісний потенціал предмета - Екологічна грамотність і здорове життя:

Уміння: працювати в команді під час реалізації географічних проектів, застосовувати набутий досвід задля збереження власного здоров'я та здоров'я інших, оцінювати значення географічної науки для забезпечення добробуту людства. 
Ставлення: турбота про здоров'я своє та інших людей, ціннісне ставлення до навколишнього середовища як до потенційного джерела здоров'я, добробуту та безпеки людини і спільноти, усвідомлення важливості ощадного природокористування, пошанування внеску кожного / кожної в досягнення команди.

Навчальні ресурси: кооперативне навчання, партнерські технології, проекти.

Екологічна культура залежить від багатьох чинників. Роль освіти у формуванні екологічної культури важко переоцінити. Як зазначив відомий італійський еколог А. Траверсо, «У міру того, як наше розуміння взаємовідносин діяльності людини і проблем навколишнього середовища поглиблюється, основні принципи освіти в галузі оточуючого середовища, якщо вони правильно вироблені, можуть цілком стати тим ядром, навколо якого формуватиметься майбутня стратегія суспільної освіти, вона сформує громадян світу 3 новим світоглядом, 3 новими настроями, які більше відповідатимуть потребам людства і природи».

Сучасна екологічна ситуація в світі та в Україні зокрема загострюється 3 кожним днем. Забруднення атмосфери шкідливими викидами, тисячі тон сміття, знищення цілих екосистем через вирубування лісів, розорювання, будівництво, шкідлива радіація та випромінювання далеко не повний перелік тих техногенних факторів, які негативно впливають на екологію. Недарма екологічне виховання визнане одним із найважливіших пріоритетів ЮНЕСКО, Національної доктрини розвитку освіти України XXI століття, інших основоположних документах світового та національного рівня.

Екологічне виховання це вже не лише формування відповідних знань і вмінь у взаємодії людини та природи, а й розвиток засобами педагогічних технологій особистості, спеціальних знань, ціннісних норм та орієнтацій щодо усвідомлення екологічної цінності природного середовища у його нерозривній єдності з людиною. Ключовою метою екологічного виховання на уроках і в позаурочний час $є$ формування відповідального та дбайливого ставлення до природи, що базується на: екологічній свідомості та самосвідомості формуванні стійкої потреби власного свідомого дотримання екологічних принципів природокористування, розвитку навичок екологічної куль- 
тури, активній участі в суспільно корисній праці з захисту, догляду та оптимізації стану довкілля, пропаганді в найширших межах екологічних знань активній діяльності з вивчення та охорони природи своєї місцевості.

\section{2. Екологічна освіта}

До екологічної освіти висувають наступні вимоги:

1. Дати уявлення учням про навколишнє середовище 3 різних його аспектів: природного, створеного людиною, технологічного і соціально-екологічного, політичного, культурного, історичного, естетичного.

2. Починатись 3 дошкільного віку дитини і продовжуватися на всіх рівнях його освіти, а також самоосвіти.

3. В шкільній освіті бути пов'язаною не тільки з екологією, а носити міждисциплінарний характер, тобто включати спеціальний зміст у кожний навчальний предмет.

4. Досліджувати головні проблеми навколишнього середовища не тільки з теорії глобальної, а враховувати місцеві, національні та міжнародні точки зору.

5.Зосереджувати увагу на поточних екологічних ситуаціях, а також моделювати майбутні, для їх попередження.

6. Доносити до суспільства значення міжнародного екологічного співробітництва.

7. Докладно висвітлювати різні аспекти навколишнього середовища в процесі соціально-економічного планування і розвитку.

8. Давати можливість населенню застосовувати свої знання і досвід у плануванні, прийнятті рішень і визначенні наслідків.

9.Носити до суспільства важливість екологічної освіти будь-якої вікової групи, але надавати особливого значення розвитку розуміння чутливості навколишнього середовища в учнів у ранньому віці.

10. Допомагати учням визначати ознаки виникнення проблем навколишнього середовища.

11. Набуття навичок вирішувати проблеми навколишнього середовища, що з'являються.

12. Використовувати різноманітність навколишнього середовища, що вивчається, і широкий набір методичних прийомів для навчання, засвоєння знань про дозвілля [2, с. 171-172]. 
Відповідно до Концепції екологічної освіти України, екологічна освіта повинна охоплювати всі вікові, професійні та соціальні версти населення, і грунтуватися на таких принципах:

- системність і безперервність, що забезпечують умови формування екологічної культури між окремими ланками освіти, єдність формальної і неформальної освіти;

- орієнтацію на ідею цілісності природи; міждисциплінарний підхід до формування екологічного мислення, що передбачає логічне поєднання й поглиблення системних природних знань;

- взаємозв'язок краєзнавства, національного і глобального мислення, що сприяє поглибленому розумінню екологічних проблем на різних рівнях; конкретність та об'єктивність знань, умінь та навичок; поєднання високопрофесійних екологічних знань з високоморальними цінностями $[4$, с. 5-7, 10].

Екологічна освіта і виховання повинні орієнтуватись на активну взаємодію людини з природою, побудовану на науковій основі, на оцінюванні людини як частини природи. Екологічні знання, доповненні ціннісними орієнтаціями, повинні стати основою екологічної культури і екологічного мислення. Вони мають сприяти усвідомленню цінностей, допомагати вирішенню комплексних екологічних проблем, що стоять перед людством, забезпечити комфортність його проживання у майбутнього, зберегти та примножити унікальну різноманітність всієї біоти і зокрема рослинного та тваринного світу [5, с. 58-61].

\section{3. Основні принципи, на яких грунтується розробка навчальних екологічних карт}

Методично правильне оформлення навчальних географічних атласів грає важливу роль в набутті власне картографічних знань, в навчанні використанню карти як джерела знань, у всьому процесі навчання географіï.

При укладанні карт атласу автори мають звернути увагу на деякі моменти:

1.Сувора відповідність змісту карт навчальній програмі. Дана вимога $є$ пріоритетним і в зв'язку з цим позначена першою. Основна відмінність навчальних від звичайних екологічних картографічних творів, це те, що вони укладаються відповідно до навчальної програми, 
затвердженої Міністерством освіти та науки України. Тобто, крім стандартних джерел для створення карт (матеріали дистанційного зондування Землі, літературні джерела, статистичні дані і т д), потрібно в першу чергу керуватись програмою.

Освітня програма - це єдиний комплекс освітніх компонентів, спланованих і організованих закладом загальної середньої освіти для досягнення учнями результатів навчання. Основою для розроблення освітньої програми є Державний стандарт загальної середньої освіти відповідного рівня. Приклад освітньої програми наведено нижче у табл. 1 .

Незважаючи на високий статус картографічних видань в освітньому процесі карта (і атлас) повинна виконувати, перш за все, функцію ілюстрації навчального матеріалу, представленого в програмі або ж пояснюється в ході уроку вчителем. У разі повної самостійності карти, їі невідповідності хронологічних рамок теми необхідність такого навчального посібника, можливість його використання в процесі навчання можуть стати дуже сумнівними. Карта повинна ілюструвати той матеріал, ті події, процеси і явища, які зазначені в шкільній програмі. В іншому випадку карти і атласи не сприятимуть освітнім цілям, заплутають і вчителі, і учнів.

У той же час, значною допомогою в процесі навчання служать ті карти і атласи, які наочно відображають ту інформацію, яка викладена в підручнику. Безумовно, зміст карт вимушено виходить далеко за рамки тієї інформації, яку містить підручник. Показані міста і держави, які в підручниках навіть не згадуються, відображені зміни кордонів, які в підручниках, природно, не описуються. Проте, на картах слід застосовувати ту ж термінологію, що й в підручнику, то ж хронологічний поділ, враховувати пріоритет тих подій, які описані в підручниках, щоб карта не виявилася перевантаженою, а другорядні події не заступили головні.

У той же час зміст карти може і повинен бути трохи ширше інформації, наданої підручником. По-перше, підручник відносно бідно висвітлює територію держави, iї географічні особливості, сусідство та різні екологічні характеристики. По-друге, є маса інформації, яка зовсім не відображена в навчальних посібниках, але без якої неможливо обійтися.

2.При використанні карт в процесі навчання слід звернути увагу на труднощі співвіднесення учнями подї̈ або явища, зображеного на 
Таблиця 1

Навчальна програма для 11 класу загальноосвітніх навчальних закладів рівень стандарту, академічний рівень

\begin{tabular}{|c|c|c|}
\hline 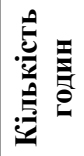 & Зміст навчального матеріалу & Навчальні досягнення учнів \\
\hline 2 & $\begin{array}{l}\text { Тема 1. Екологія як наука про } \\
\text { довкілля } \\
\text { Предмет, об’єкт, завдання і методи } \\
\text { науки про довкілля. Структура } \\
\text { сучасної екології та їі місце в системі } \\
\text { наук. }\end{array}$ & $\begin{array}{l}\text { Учень: } \\
\text { • Розуміє екологію як комплексну } \\
\text { складну багатогранну науку про } \\
\text { взаємовідносини живої і неживої } \\
\text { природи про тактику і стратегію } \\
\text { збереження та збалансованого } \\
\text { розвитку життя на землі; } \\
\text { • Знає складну структуру } \\
\text { екології, яка об'єднує два } \\
\text { основні напрямки: теоретичний } \\
\text { (класичний) і прикладний }\end{array}$ \\
\hline 2 & $\begin{array}{l}\text { Тема 2. Природа і людина: } \\
\text { системний підхід } \\
\text { Властивості складних систем. } \\
\text { Біосфера, основні положення вчення } \\
\text { В. І. Вернадського про біосферу. } \\
\text { Еволюція уявлень про роль і місце } \\
\text { природи у житті суспільства. } \\
\text { Ноосфера. Еволюція уявлень про } \\
\text { місце людини у природі. Історичні } \\
\text { етапи взаємодії суспільства і } \\
\text { природи та їх екологічні особливості. } \\
\text { Масштаби і наслідки антропогенного } \\
\text { впливу на природне середовище на } \\
\text { сучасному етапі. } \\
\text { Практична робота: «Аналіз } \\
\text { особливостей історичних етапів } \\
\text { взаємодії суспільства і природи». }\end{array}$ & $\begin{array}{l}\text { Учень: } \\
\text { розуміє сутність складних } \\
\text { систем; роль живої природи } \\
\text { в організації біосфери; місце } \\
\text { природи у житті суспільства; } \\
\text { рушійну силу людського розуму } \\
\text { у формуванні ноосфери; місце } \\
\text { людини у природі; досліджує } \\
\text { особливості основних етапів } \\
\text { взаємодії суспільства і } \\
\text { природи; аналізує наслідки } \\
\text { змін і перетворень природних } \\
\text { процесів і компонентів природи } \\
\text { антропогенною діяльністю. }\end{array}$ \\
\hline
\end{tabular}

тематичній карті в масштабі, скажімо, однієї держави, з місцем цієї події або явища, та й самої держави на карті світу або частини світу. Приклад даного принципу наведено на рис. 1.

В результаті просторове сприйняття, прив'язка будь-яких подій і явищ до географічної карти, просто не формується. Тому важливо 
уявити конкретну карту в контексті великого регіону. Виконати це можна різними способами. Наприклад, врізкою на настінній карті атласу можна дати схематичне зображення частини земної кулі, в якому яскравим кольором виділити ту ділянку території, яка представлена на основний карті. Або помістити поруч різномасштабні карти, в одній з яких уявити безпосередньо територію, на якій відбувалися досліджувані події і процеси, а на другий - місце пріоритетного в даному випадку регіону на оглядовій карті [10, с. 18-25].

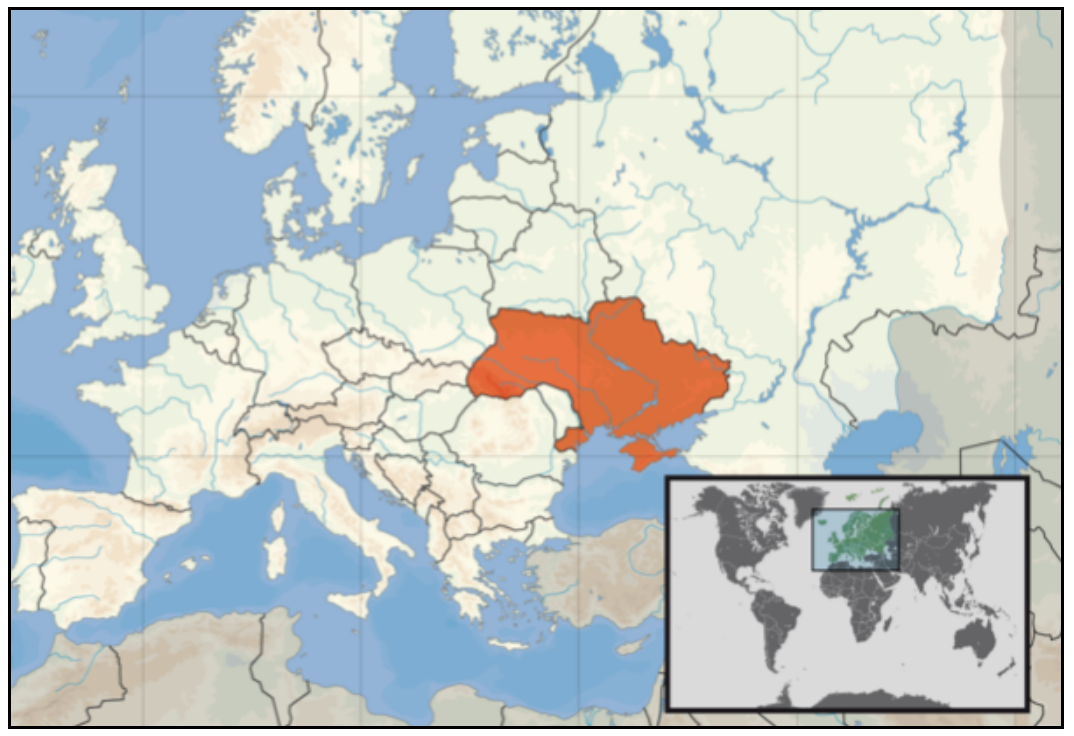

Рис. 1. Карта «Географічне положення України»

3. Врахування вікових особливостей - одне з основоположних педагогічних вимог, що пред'являються до створення екологічних навчальних посібників. На рис. 2, що знаходиться нижче, наведено різницю подання інформації на картах для 5-го та 8-го класах.

Спираючись на нього, слід регламентувати склад, зміст і навантаження карт, встановлювати обгрунтовані обсяги, що мають міститись в картах, інформації, визначати найбільш сприятливий для сприйняття різними віковими групами учнів зовнішній вигляд карт, кольо- 
ропередачу, розмір різних елементів (шрифти, значки, лінії кордонів і т. д.). Вікові особливості зобов'язують правильно вирішувати питання відбору та розташування на аркуші різних елементів карти (легенда, врізки, назва), змушують враховувати рівень розвитку абстрактного мислення, співставляти смислове навантаження з можливістю іiї аналізу з боку учня.

Так, карти в 5-6 класах повинні бути досить прості, число елементів в них повинно відповідати здібностям учнів адекватно сприйняти їх. При першому ж візуальному сприйнятті карти учні повинні мати можливість повністю тримати іiі в полі зору. При цьому потрібно враховувати межі короткочасної оперативної пам'яті учнів. Дуже важливо в умовах сучасної школи правильно вибрати масштаб карти, величину шрифтів і значків. Наприклад, що стосується стінних карт, то учні, які сидять навіть на перших партах в класі не завжди здатні розгледіти на настінній карті навіть основні елементи. У зв'язку з цим можливий новий підхід до створення настінних карт, при якому основним стає наголос на інформацію, що має не текстовий і значковий характер, а реалізовану за допомогою кольорових плям, великих об'єктів [9, с. 521-536].

При цьому сама карта повинна бути максимально доступна для розуміння, вона не повинна містити складних, неоднозначно інтерпретованих або погано помітних елементів. Психологами виявлено також, що заучування в цілому ефективніше заучування по частинах. Тому важливо, особливо при роботі з картами, дати цілісне розуміння обумовленості присутності в наочних конструкціях всіх їх елементів і складання їх у єдине ціле.

Таким чином, при роботі над картою необхідно враховувати вікові, психологічні та фізіологічні особливості учнів. Це і спрощена лексика, і надмірна насиченість інформацією. Необхідно застосовувати великі значки, контрастні, але в той же час, м'які, які не подразнюють зір, великий чіткий шрифт і т. д. [10, с. 15-18].

4. Карта повинна служсти тим засобом, завдяки якому в учнів може виявитися інтерес до навчання в цілому. Красиво оформлена, наочна, приємна для сприйняття карта, крім того, виконує виховну функцію. Погано зроблена карта, що викликає нерозуміння і навіть роздратування у користувача в результаті може привести до небажання вивчати навчальний предмет. 


\section{Chapter «Geographical sciences»}

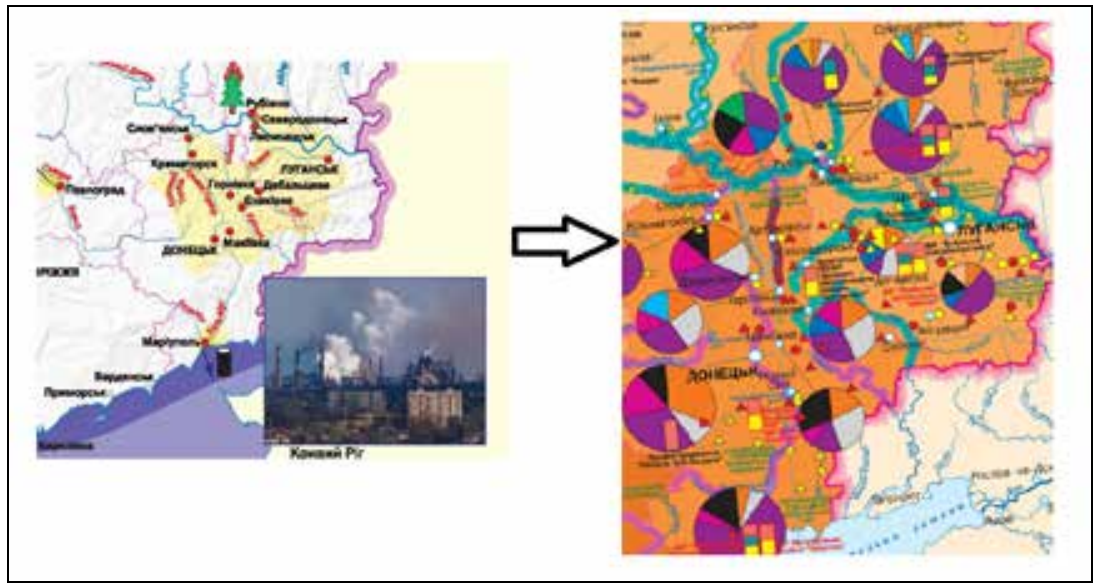

Рис. 2. Відмінність подання екологічної інформації на картах «Екологічна ситуація» шкільних атласів для 5-го та 8-го класу

Карти, що використовуються на уроках в загальноосвітніх установах, повинні бути найбільшою мірою адаптовані для візуального сприйняття учнями. Тут мається на увазі: яскравість (але не надмірна) зображення, розміщення в зручному для сприйняття місці, оптимальний масштаб, контрастне виділення окремих елементів і т.д.

5. Карта повинна залишатися одним з основних засобів навчання. Ось кілька можливостей її застосування: 1. Ілюстрація розповіді вчителя, акцентування уваги учнів на подіях і явищах шляхом фіксування їх на карті (включається зорова пам'ять). 2. Самостійне вивчення карти учнями. Карта - наочний засіб навчання, що привертає увагу школярів, зацікавлюють їх, прищеплює інтерес до історії. 3. Формування просторового мислення, уявлення про місце своєї країни, іiї історії, подій 3 нею пов'язаних на світовій мапі. Знання розташування тієї чи іншої держави на карті, сусідів, що його оточують, природного середовища (гори, моря і т. д.) дає розуміння відбувалися процесів.

6. Створення карт і атласів з урахуванням принципу науковості. У разі застосування в навчальному процесі картографічного матеріалу вимога дотримання принципу науковості має особливе значення, оскільки складові карти, iї внутрішнє наповнення може довго утримува- 
тися в пам'яті учнів і, в зв'язку з цим, накладатися і поєднуватися з іншим досліджуваним матеріалом. При створенні карт необхідно враховувати досягнення екологічної та картографічної науки, використовувати тільки перевірені дані, засновані на автентичних і найбільш несуперечливих джерелах. Не потрібно вводити в наочні посібники спірні, дискусійні моменти. При цьому необхідно уникати того, щоб карти перетворювалися з наукових за змістом в наукоподібні за формою [8, с. 25-32].

7. Дотримання принщипу систематичності при створенні атласів $i$ оформлення карт.

Вимога дотримання принципу систематичності стосовно створення карт виражається в логічній послідовності відображених на них об'єктів, явищ і процесів, що реалізується, перш за все, в умовних позначеннях (легендах) до карти. Така послідовність виражається в поступовості і поступальності відображення на карті подій і явищ, що забезпечує легкість їх розуміння і запам'ятовування в цілому. Розрив зв'язку в послідовності викладу навчального матеріалу в загальному призведе до повної неузгодженості внутрішнього змісту карти.

8. Відповідність естетичним $i$ етичним критеріям. Навчальна візуальна інформація на картах повинна відповідати естетичним критеріям (відповідати композиційним вимогам: симетрії, ритму, ракурсу, контрасту і локалізації смислового центру, перспективі і колориту) i етичним критеріям (відповідність змістовним і формальним нормам моралі). У зв'язку з цим можна зробити висновок, що створення карт це не механічний процес нанесення певної кількості елементів на аркуш паперу, але і творчість, спрямована на правильне сприйняття карти.

9. Урахування принцииу доступності для розуміння.

Карти, які вчитель може запропонувати на уроках, в загальних рисах, в основних принципах їх побудови повинні бути знайомі і доступні для сприйняття учням. Розглядаючи карти, які є умовним відображенням місцевості, вони повинні розуміти ті принципи, за якими нанесені річки, кордони, пунсони (умовні знаки, що визначають місця розташування населених пунктів) і т. д. Типовість та однотипність карт полегшує їх читання учнями, яким не потрібно додатково пояснювати зміст того чи іншого елемента карти і можна зосередити їх увагу тільки на внутрішній зміст наочних засобів навчання, які допомагають вивчити нову тему [2, с. 171-172]. 
Наприклад, на карті «Екологічна ситуація України» для 5-го класу, для картографування знеліснення в якості умовних позначень обрали значки ялини. При показі особливо забруднених територій використовували більш темний, насичений колір. Фрагмент карти наведено нижче на рис. 3.

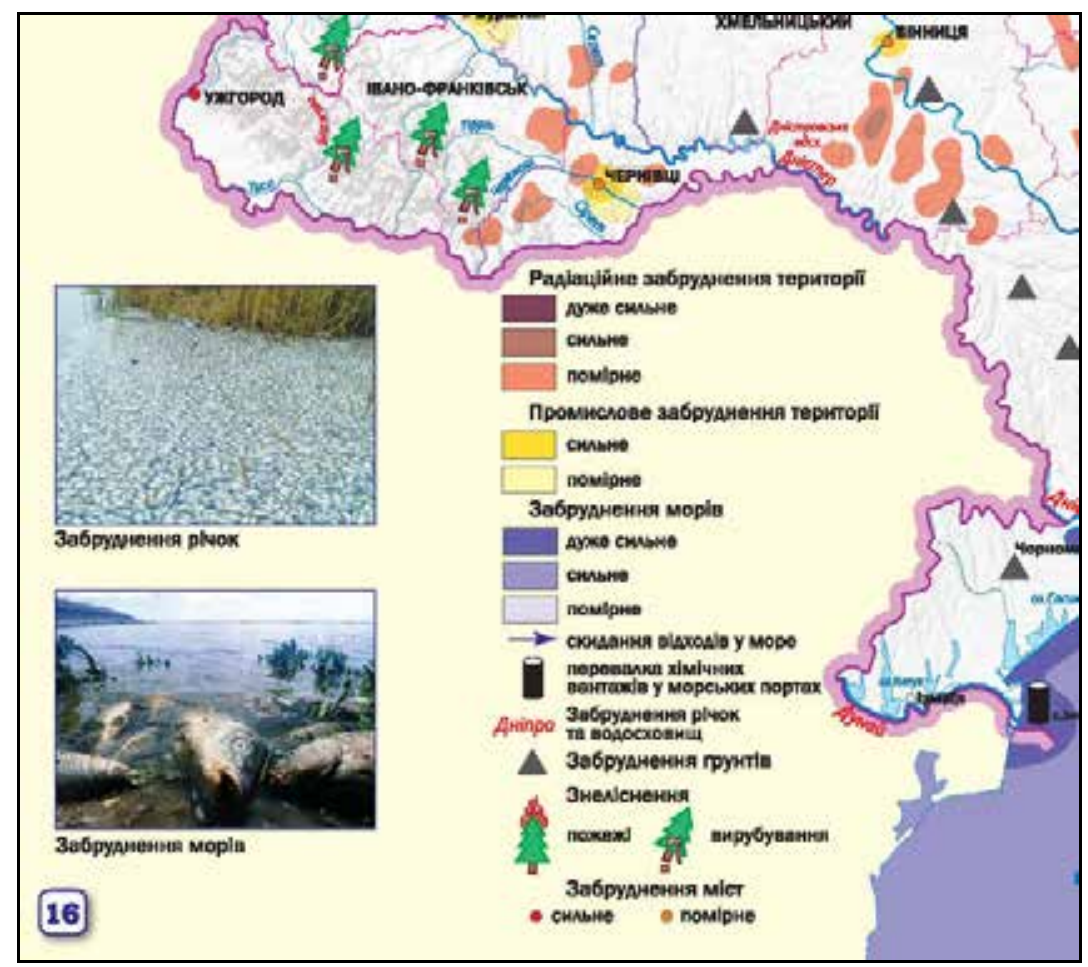

Рис. 3. Фрагмент карти «Екологічна ситуація України» для 5-го класу

10. Прагнення до створення умов для міџності засвоєння знань.

Процес міцного засвоєння знань є дуже складним. Традиційно вважалося, що навчання має грунтуватися на довільному запам'ятовуванні, що має свої підстави. Однак до теперішнього часу помічено, що в багатьох випадках мимовільне запам'ятовування $є$ навіть більш продуктивним, ніж довільне. Розуміння цього збільшує значення карт, так 
як їх використання збільшує рівень мимовільного запам'ятовування. Проте, інтенсифікуючи мимовільне запам'ятовування учнів, не слід давати прямих завдань чи вказівок: краще зацікавити учнів, час від часу «підігрівати» виникнення інтересу, час від часу звертаючи увагу на карту.

11. Вимога дотримання принципу свідомості навчання.

Сутність освіти складають глибоко і самостійно осмислені знання, що здобуваються шляхом інтенсивної напруги власної розумової діяльності. Свідоме засвоєння знань учнями залежить від ряду умов і факторів: мотивів навчання, рівня і характеру пізнавальної активності учнів, організації навчального процесу та управління пізнавальною діяльністю учнів, що застосовуються викладачем методів і засобів навчання та ін. Власна пізнавальна активність також є важливим фактором навченості і робить вирішальний вплив на темп, глибину і міцність оволодіння навчальним матеріалом. Звісно ж, що застосування в навчанні карт природним чином стимулює пізнавальну активність учнів і формування свідомості навчання. Ніщо так не сприяє виникненню свідомості навчання, як творча активність. Застосування в процесі навчання настінних карт, контурних карт розвиває творче мислення, призводить до стійкого позитивного ставлення учнів до процесу навчання в загальному [6, с. 13-15].

12. Орієнтація на формування патріотичних почуттів, любові до Батьківщини.

На рис. 4 наведені елементи патріотизму, що використовуються на картах.

\section{3. Функиіональна придатність}

У зв'язку з недотриманням ряду вимог, перерахованих вище, може виникнути питання про функціональну придатність карт і атласів, призначених для застосування в процесі навчання. Так, одне лише недотримання вимоги відповідності навчальній програмі і матеріалу підручника зробить наочну, науково обгрунтовану, доступну для розуміння карту функціонально непридатною для використання в процесі навчання.

\section{4. Практичність}

Як і до кожного продукту, виробленого людиною для певних цілей, до карти і атласу має бути пред'явлена вимога практичності. Ця вимога 


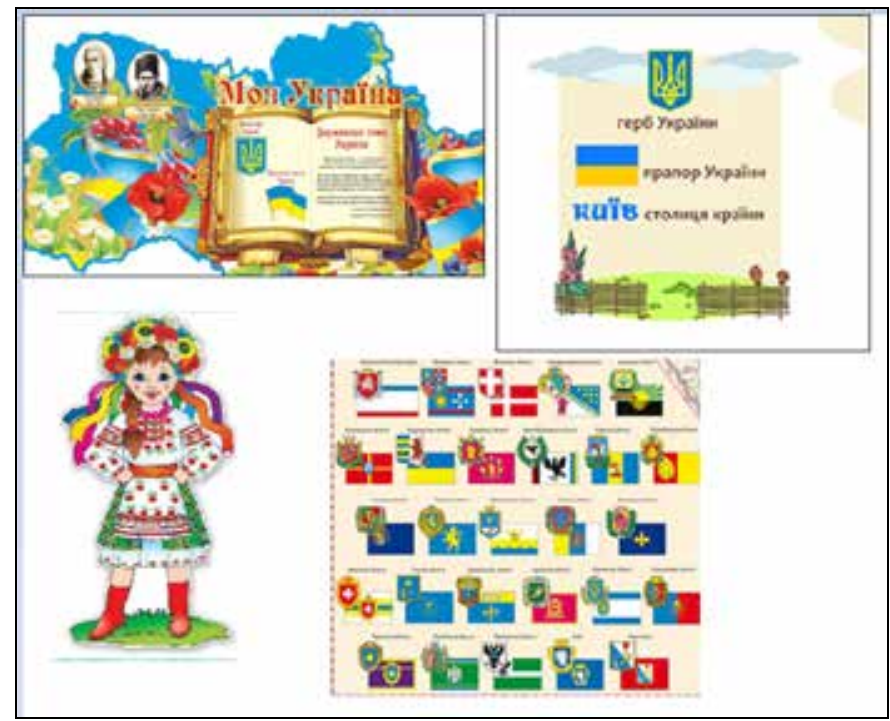

Рис. 4. Елементи, що виховують патріотизм, на різних картах

дає розуміння того, наскільки представлена форма реалізації карти зручна для використання в якості навчального посібника в процесі навчання (як для вчителя, так і для учня).

15. Важливе методичне значення має використання малюнків та фотографіï. Вони мають на меті привернути увагу дітей до карти, до матеріалу, необхідного до вивчення. Особливо такий прийом використовується на картах для дітей молодшого віку [9, с. 521-536]. На рис. 5 наведено приклад використання малюнків для кращого сприйняття інформації школярами.

\section{4. Висновки}

Система екологічної освіти в Україні продовжує бути фрагментарною (несистематизованою), слабкою концептуально, декларативною, а, отже, неефективною. Екологічні питання погано вписуються в систему ринкових відносин, а головне - їхнього задоволення. Екологічний світогляд орієнтований на інші цінності - життя людини у чистому середовищі, збереження усіх форм життя. Критична ситуація 


\section{Yuliia Nizhynska, Liudmyla Datsenko}

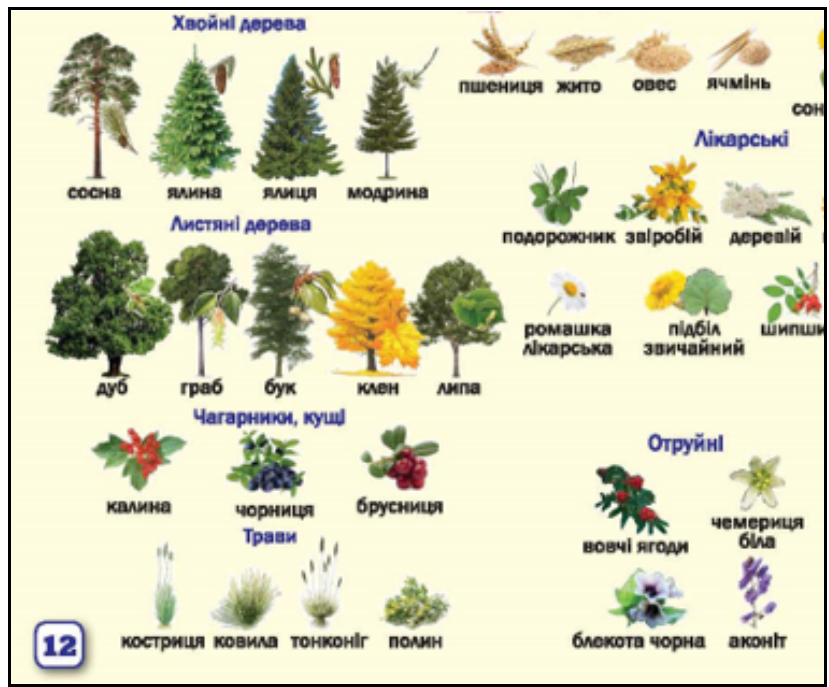

Рис. 5. Елементи карти

«Природні зони та природоохоронні території»

в галузі екологічної освіти пояснюється такими причинами, як багаторічне панування споживацького ставлення до природи; незнання та руйнування народних традицій раціонального природокористування; недооцінка екологічних знань у системі освіти.

На сучасному етапі розвитку суспільства, в період економічних реформ і бурхливого індустріального розвитку, освіта і екологічна освіта є основним фундаментом людського розвитку.

Сучасна екологічна освіта включає в себе безперервний комплексний процес формування екологічного світогляду, екологічної свідомості та культури всіх верств населення, соціальних груп і суспільства, в цілому. Таким чином екологічна освіта - це сукупність наступних компонентів: екологічні знання - екологічне мислення - екологічний світогляд - екологічна етика екологічна культура.

Існує ряд методологічних принципів розробки екологічної карти. Якщо їх дотримуватись, то грамотно створена шкільна карта допоможе у вирішенні навчальних, виховних і розвиваючих цілей в освітньому процесі. 


\section{Список літератури:}

1. Баранова Л. Г. Особливості та значення екологічного картографування на сучасному етапі / Л. Г. Баранова // Часопис картографії. - 2014. - Вип. 11. - С. 5-9.

2. Берека А. Д., Червонецький В. В. Екологічна відповідальність як показник елементарної культури особистості / Бегека А. Д., Червонецький В. В. // Національна еліта та інтелектуальний потенціал України: матеріали міжнар. конф. - Л., 1996. - С. 171-172.

3. Бойченко С. В. Екологічна освіта - основа сталого розвитку суспільства / С. В. Бойченко, Т. В. Саєнко. - К.: Університет «Україна», 2013. - 502 с.

4. Екологічна освіта для сталого розвитку у запитаннях та відповідях : науково методичний посібник для вчителів / Бондар О. І. [та ін.]. - Херсон : Грінь Д. С., 2015. - 228 с.

5. Іванова Т. В. Екологічна освіта як базова складова екологічної політики держави / Т. В. Іванова // Вісник Національного авіаційного університету. Серія: Педагогіка, Психологія. - 2017. - С. 58-61.

6. Іванченко А. В. Екологічна освіта - важливий чинник формування особистості старшокласника / А. В. Іванченко // Вісн. Житомир. держ. ун-ту ім. І. Франка. - 2003. - № 13. - С. 13-15.

7. Коновалова, И.Г. [Рецензия] // Древнейшие государства Восточной Европы. 2006 год: Пространство и время в средневековых текстах: сб. науч. ст. и рец. - М.: РАН, УН-т Дмитрия Пожарского, 2010. - С. 521-536. - Рец. на моногр.: И. К. Фоменко. Образ мира на старинных портоланах. Причерноморье.

8. Кочуров Б. И. Картографирование экологических ситуаций (состояние, методология и перспективы) / Б. И. Кочуров, Н. А. Жеребцова // География и природные ресурсы. - 1995. - № 3. - С. 18-25.

9. Про концепцію екологічної освіти в Україні [Електронний ресурс]. Режим доступу: http://consultant.parus.ua/?doc $=01 \mathrm{E} 1 \mathrm{O} 32 \mathrm{CC} 0$

10. Темушев В. Н. О подготовке настенных карт и атласов для учреждений образования, обеспечивающих получение общего среднего образования // Гісторыя: праблемы выкладання. - 2006. - № 11. - С. 15-18.

\section{References:}

1. Baranova L. Gh. (2014). Osoblyvosti ta znachennja ekologhichnogho kartoghrafuvannja na suchasnomu etapi [Features and importance of environmental mapping at the present stage]. Chasopys kartoghrafiji, vol. 11, pp. 5-9.

2. Bereka A. D., Chervonecjkyj V. V. (1996). Ekologhichna vidpovidaljnistj jak pokaznyk elementarnoji kuljtury osobystosti [Environmental responsibility as an indicator of the elementary culture of personality]. Nacionaljna elita ta intelektualjnyj potencial Ukrajiny: materialy mizhnar. konf., pp. 171-172.

3. Bojchenko S. V. (2013). Ekologhichna osvita - osnova stalogho rozvytku suspiljstva [Environmental education is the basis of sustainable development of society]. Kyev: Universytet «Ukrajina».

4. Bondar O. I. (2015). Ekologhichna osvita dlja stalogho rozvytku u zapytannjakh ta vidpovidjakh: naukovo metodychnyj posibnyk dlja vchyteliv [Environmental 
education for sustainable development in questions and answers: a scientific and methodological manual for teachers]. Kherson : Ghrinj D.S.

5. Ivanova T. V. (2017). Ekologhichna osvita jak bazova skladova ekologhichnoji polityky derzhavy [Environmental education as a basic component of state environmental policy]. Visnyk Nacionaljnogho aviacijnogho universytetu. Serija: Pedaghoghika, Psykhologhija, pp. 58-61.

6. Ivanchenko A. V. (2003). Ekologhichna osvita - vazhlyvyj chynnyk formuvannja osobystosti starshoklasnyka [Environmental education is an important factor in the formation of the personality of a high school student]. Visn. Zhytomyr. derzh. un-tu im. I. Franka, no 13, pp. 13-15.

7. Konovalova Y. Gh. (2010). Drevnejshye ghosudarstva Vostochnoj Evropy. 2006 ghod: Prostranstvo y vremja v srednevekovykh tekstakh: sb. nauch. st. y rec. RAN, Un-t Dmytryja Pozharskogho, pp. 521-536. - Rec. na monoghr.: Y. K. Fomenko. Obraz myra na starynnykh portolanakh. Prychernomorje [The image of the world on ancient portolans. Black Sea].

8. Kochurov B. Y. (1995). Kartoghrafyrovanye ekologhycheskykh sytuacyj (sostojanye, metodologhyja y perspektyvy) [Mapping of environmental situations (status, methodology and prospects)]. Gheoghrafyja y pryrodnye resursy, no 3, pp. 18-25.

9. Pro koncepciju ekologhichnoji osvity v Ukrajini [About the concept of environmental education in Ukraine]. URL: http://consultant.parus.ua/?doc $=01 \mathrm{E}-$ $1 \mathrm{O} 32 \mathrm{CC} 0$

10. Temushev V. N. (2006). O podghotovke nastennykh kart y atlasov dlja uchrezhdenyj obrazovanyja, obespechyvajushhykh poluchenye obshhegho srednegho obrazovanyj [About the preparation of wall maps and atlases for educational institutions providing general secondary education]. Ghistoryja: prablemy vkladannja, no 11, pp. $15-18$. 